\title{
Social organization and space use in the Cape porcupine in a Southern African savanna
}

\author{
NIALL U. CORBET and RUDI J. VAN AARDE* \\ Mammal Research Institute, University of Pretoria, Pretoria 0002, South Africa
}

\section{Summary}

Six male and four female adult Cape porcupines (Hystrix africaeaustralis) were radiotracked between July 1989 and June 1990 in a southern African savanna in order to investigate their social organization and space-use patterns. They lived in family groups based upon monogamous adult pairs. Pair members shared burrows and home range areas and all pairs were stable for the duration of the study. It is suggested that the occurrence of family groups is largely dependent on the opportunities available for mature offspring to disperse from their natal group. Individual home ranges occupied the same general location throughout the year although the exact area used varied from month to month and most activity was concentrated in a relatively small portion of a potentially larger area. Natural foragers had significantly larger home ranges in winter than in summer. Crop foragers exhibited no significant seasonal difference in range size.

Home range overlap between natural foraging neighbours was greatest in winter but even then was not extensive, there being little overlap between neighbouring $95 \%$ and $90 \%$ home ranges. It is therefore suggested that porcupines are territorial, maintaining a small, exclusive territory within a larger, non-exclusive home range. Neighbours rarely encountered one another in the areas of overlap and territories were probably maintained by scent marking rather than through direct interactions.

Key words: home range, monogamy, porcupine, social, territoriality

\section{Résumé}

Des porcs-épics du Cap (Hystrix africaeaustralis), six mâles et quatre femelles adultes, ont été suivis par radiotracking entre juillet 1989 et juin 1990 dans une savane sud-africaine pour étudier leur organisation sociale et le schéma de leur utilisation du territoire. Ils vivaient en groupes familiaux basés sur une paire d'adultes monogames. Les membres du couple partagaient le même terrier et le même espace vital, et tous les couples sont restés stables jusqu'à la fin de la recherche. On suggère que l'existence de groupes familiaux dépend largement des possibilités dont dispose la descendance mature de se disperser à l'écart du groupe d'origine. Les espaces vitaux respectifs occupaient globalement le même territoire tout au long de l'année même si l'endroit précis variait de mois en mois et que la plus grande partie de leur activité se déployait dans une portion relativement resteinte d'un espace potentiellement plus étendu. Ceux qui se

*Cortespondence address

(C) 1996 East African Wild Life Society. 
nourrissaient en nature disposaient d'un territoire significativement plus vaste en hiver qu'en été alors que ceux qui se nourrissaient sur les cultures ne présentaient pas de différence significative dans ce domaine.

Le recouvrement des espaces vitaux des animaux qui se nourrissaient en nature était plus important en hiver qu'en été, mais même alors il n'était pas très grand, car il y avait peu de recouvrement entre 90 à $95 \%$ des espaces vitaux avoisinants. C'est pourquoi on suggère que les porcs-épics sont territoriaux, et conservent un petit territoire exclusif inclus dans un espace vital plus étendu mais non exclusif. Les voisins se rencontrent rarement dans les endroits de recouvrement, et les territoires sont probablement gardés au moyen de marques olfactives plutôt que par des interactions directes.

\section{Introduction}

Cape porcupines, Hystrix africaeaustralis Peters, are large ( $10-24 \mathrm{~kg}$ ) nocturnal hystricomorph rodents. They are distributed throughout southern Africa where they inhabit extensive burrow systems, caves and rock crevices (Skinner \& Smithers, 1990). Porcupines feed mainly on geophytes, roots and bark but will also cause extensive damage to cultivated crops (Van Aarde, 1987a; Yeaton, 1988; De Villiers \& Van Aarde, 1994).

The social organization of the Cape porcupine has not been studied extensively, although it is known that they live in pairs or small groups (Van Aarde, 1987b). In captivity and in the wild extended family groups do develop, these consisting of a monogamous adult pair with both their mature and immature offspring (Morris \& Van Aarde, 1985). Sexual maturity is reached at approximately one year of age (Van Aarde, 1985a) but conception in sexually mature offspring is suppressed until after dispersal from their natal groups (Van Aarde \& Van Wyk, 1991).

Captive porcupines scent-mark their enclosures and aggressively defend them against conspecifics (personal observations). Such behaviour suggested that Cape porcupines may be territorial although this had not been studied in free-ranging animals. The present study aimed at investigating the social organization and space-use patterns of free-ranging Cape porcupines living in a savanna by means of an intensive radiotracking programme. Such information is essential for an understanding of the ecology and population biology of porcupines and is vital if management or conservation programmes are to be successfully implemented. In this paper observations on the social organization and space-use patterns of the Cape porcupine are interpreted in terms of some existing hypotheses on the influence of environmental factors on these variables.

\section{Study area}

Fieldwork was conducted on a part of the Nylsvley Nature Reserve $\left(24^{\circ} 39^{\prime} \mathrm{S}\right.$, $28^{\circ} 42^{\prime} \mathrm{E}$ ) in the northern Transvaal, South Africa. A detailed description of the study area is provided by Scholes \& Walker (1993). The area comprised 3000 ha of mixed grassland and deciduous woodland savanna (Coetzee et al., 1976) with adjacent farmland where maize and melons were cultivated. The climate is clialacterized by hol, wet summers (October to March) and cool, dry winters 
(April to September). The study area extended over 745 ha and comprised four distinct plant communities described in detail by Coetzee et al. (1976). The selective use of these habitats by porcupines has been described by De Villiers, Van Aarde \& Dott (1994).

\section{Methods}

\section{Trapping and radiocollaring}

Drop-door traps baited with sweet potatoes, maize cobs or apples, were placed close to burrow entrances located during preliminary field surveys. Captured porcupines were transferred to a custom-built crush box before being immobilized by an intramuscular injection of $70 \mathrm{mg}$ ketamine hydrochloride (Ketamine; Parke-Davis Laboratories (Pty) Ltd, Isando, RSA) and $10 \mathrm{mg}$ xylazine hydrochloride (Rompun; Bayer Pharmaceuticals (SA) (Pty) Ltd, Johannesburg, RSA) (Van Aarde, 1985b). Data were then collected on relative age, sex and weight and a radiocollar was fitted. Each porcupine was assigned a code consisting of a letter and a number whereby $\mathrm{M}=$ male and $\mathrm{F}=$ female, the number identifying an individual and its partner, e.g. M1 is the partner of F1.

Radiocollars consisted of a Telonics MK5 transmitter with a SAFT $3.5 \mathrm{~V} \mathrm{C}$ size lithium battery (Telemetry-Electronics Consultants, Arizona, USA) embedded in dental acrylic (Taylor and Horn, Pretoria, RSA) and attached to an adjustable Trekflex belting collar (SA Belting, Pretoria, RSA) with a Telonics $30 \mathrm{~cm}$ TA-5H17 Ext. antenna. Frequencies in the range 146.200 to $150.750 \mathrm{MHz}$ were used. Total radiocollar weight was $\sim 200 \mathrm{~g}$. Estimated battery lifespan was 12 months and no failures occurred during the study.

\section{Radiotracking}

Radiocollared porcupines (six males and four females) were located at hourly intervals from dusk to dawn for a mean of $11 \cdot 5 \pm 2 \cdot 0$ (SD) nights per individual per month between July 1989 and June 1990. A Yaesu FT 290 R2 G Model (Yaesu Musen Co. Ltd, Tokyo, Japan) and a handheld Telonics RA-2AK $\mathrm{H}$-antenna were used to locate the position of individuals through triangulation. Visual contact was prevented by dense vegetation. Bearings for triangulation were taken from known locations marked at $500 \mathrm{~m}$ intervals on vehicle tracks in the study area.

Prior to commencing the radiotracking study, the accuracy of triangulation was assessed by taking bearings on radiocollars placed at known points in the study area. Using the loudest-signal method (Springer, 1979) a mean error of $+0.3 \pm 11.3^{\circ}$ was obtained. The $95 \%$ confidence limits were then calculated $(1.96 \times \mathrm{SD})$ from which the sizes of error polygons for various distances between transmitter and receiver were calculated (Springer, 1979). Maximum effective transmitter range was $1500 \mathrm{~m}$. This resulted in an average error polygon $(95 \%$ confidence limits) of $\approx 400 \mathrm{~m}^{2}$. Thus, real locations are taken to be accurate to within $20 \mathrm{~m}$ of calculated locations, although most are likely to be considerably more accurate than this. Error polygons were not used in the calculation of home lange arca but the limitations of the data were noted.

(c) East African Wild Life Society, Afr. J. Ecol., 34, 1-14 
Data analysis

Monthly home range areas for each individual were calculated from multinuclear polygon cluster analysis and minimum convex polygons utilizing a modification of Kenward's (1987) 'Program 2'. The following categories of range use were calculated:

1 Total home range of $100 \%$ cluster, defined by the minimum convex polygon which, although often containing areas not used by the animal, is taken to represent the potential home range of the individual during a month, including exploratory excursions.

2 The 95\% cluster(s), representing the area used by an individual during its usual nightly activities.

3 The 90\% cluster(s), representing the area in which most activity was concentrated, i.e. the 'core area' of the home range.

Ranges defined by clusters below the $90 \%$ level often deteriorated into large numbers of small, fragmented clusters and could therefore not be consistently used.

Individuals were classified as either natural foragers, i.e. those animals which foraged solely on natural vegetation within the reserve, or crop foragers, i.e. those that foraged on adjacent farmland as well as within the reserve. Home range size (100\%, 95\% and 90\% clusters) was calculated for each individual on a monthly basis. There was no significant correlation (Spearman rank correlation coefficient) between range size and the number of nights for which data were used to calculate range size (for all values based on at least 10 nights data) for natural foragers and crop foragers in winter and summer $(P<0 \cdot 05)$. Four of the 120 individual monthly ranges which were based on less than 10 nights data thus were not included in subsequent analyses.

Overlap between neighbouring home ranges and that for pairs was calculated using a Quantimet 520 Image Analyser (Cambridge Instruments, Cambridge, UK). Temporal space-use patterns were analysed by recording the distances between the locations of all individuals for whom locations were recorded within 10 minutes of each other. These distances were then assigned to inter-individual distance categories (IID) of $200 \mathrm{~m}$ intervals. An inter-individual distance of $<200 \mathrm{~m}$ was interpreted as suggesting that both animals were aware of each other's presence, either physically or through olfactory cues. A IID of $>201<400 \mathrm{~m}$ was taken to represent a lesser probability of such an encounter and at IIDs $>400 \mathrm{~m}$ it was assumed that no encounters occurred during that hourly period.

Due to the hourly intervals between locations and the accuracy of locations it was impossible to detect brief encounters between individuals. Thus, only when the locations of two individuals appeared to follow a similar trend and positions for three or more consecutive hourly intervals could a potential interaction be recorded.

\section{Results}

\section{Study animals}

The sex ratio of the 14 animals ( 85 and $69 q$ ) caught in the study area did not differ significantly from unity $\left(\chi^{2}=0 \cdot 14, \mathrm{df}=1, P>0 \cdot 05\right)$. None of these females 
Table 1. Mean monthly home range sizes (in ha \pm SD) of natural foragers and crop foragers in winter and in summer. Range use categories are defined in the text ( $N=$ number of home ranges)

\begin{tabular}{|c|c|c|c|c|c|c|c|c|}
\hline \multirow[b]{2}{*}{$\begin{array}{l}\text { Range use } \\
\text { category }\end{array}$} & \multicolumn{4}{|c|}{ Natural foragers } & \multicolumn{4}{|c|}{ Crop foragers } \\
\hline & $\begin{array}{r}\text { Winter } \\
N=17\end{array}$ & $\begin{array}{r}\text { Summer } \\
N=29\end{array}$ & $U$-value & $P$-value & $\begin{array}{r}\text { Winter } \\
N=8\end{array}$ & $\begin{array}{r}\text { Summer } \\
N=4\end{array}$ & $U=$ value & $P=$ value \\
\hline $100 \%$ cluster & $215 \pm 75$ & $142 \pm 61$ & $104 \cdot 5$ & $<0.01$ & $388 \pm 118$ & $376 \pm 130$ & 14 & $>0 \cdot 1$ \\
\hline $95 \%$ cluster & $116 \pm 35$ & $67 \pm 35$ & $67 \cdot 0$ & $<0.01$ & $175 \pm 58$ & $203 \pm 62$ & 14 & $>0 \cdot 1$ \\
\hline $90 \%$ cluster & $79 \pm 28$ & $40 \pm 17$ & $55 \cdot 5$ & $<0.01$ & $106 \pm 35$ & $84 \pm 17$ & 10 & $>0.1$ \\
\hline
\end{tabular}

was lactating and no juveniles were caught. Not more than two porcupines, one male and one female, were ever caught at the same burrow, suggesting that an adult pair is the basic social unit in the study area. Mean body weight $(15.4 \pm 1.3 \mathrm{~kg})$ for males and females was similar (Mann-Whitney $U=19$, $P>0 \cdot 10$ ).

Ten of these porcupines ( 6 of and 4 of ) were radiotracked for between 12 nights (114 locations) and 133 nights (1410 locations). Five males were radiotracked from their time of capture until the end of the study when they were recaptured and their radiocollars removed. Of the other five animals, one lost its radiocollar, one signal was lost during a thunder storm and never heard again, one was shot while foraging on a neighbouring farm and two died in their burrows, probably as a result of eating poisoned bait placed by landowners outside the reserve.

\section{Individual space-use patterns}

The monthly home range areas for one of the study animals are presented in Fig. 1. As for all the study animals, this individual's monthly home range areas, although showing some variation from month to month, extended over the same general area throughout the year. Each porcupine used up to six different burrows (Fig. 1) which were almost always shared by pair members. Burrows were occupied on an irregular basis, a single burrow being occupied for between one and 151 days. On any one night only a portion of the total home range was normally utilized, although there was no apparent pattern as to which area was used on a particular night. Routes taken while foraging appeared to show no regular pattern. The $95 \%$ clusters occupied on average $63 \%$ of the total home range and $90 \%$ clusters on average occupied only $32 \%$ of the total home range area. Thus, most activity took place in a relatively small proportion of the potentially available area.

\section{Home range size}

Mean home range sizes for natural foragers and crop foragers in both seasons are presented in Table 1. Natural foragers had significantly larger mean range sizes $(100 \%, 95 \%$ and $90 \%)$ in winter than in summer $(P<0.01$, Mann-Whitney $U$-test) whereas crop foragers exhibited no significant scasonal differences in

(C) East African Wild Life Society, Afr. J. Ecol., 34, 1-14 

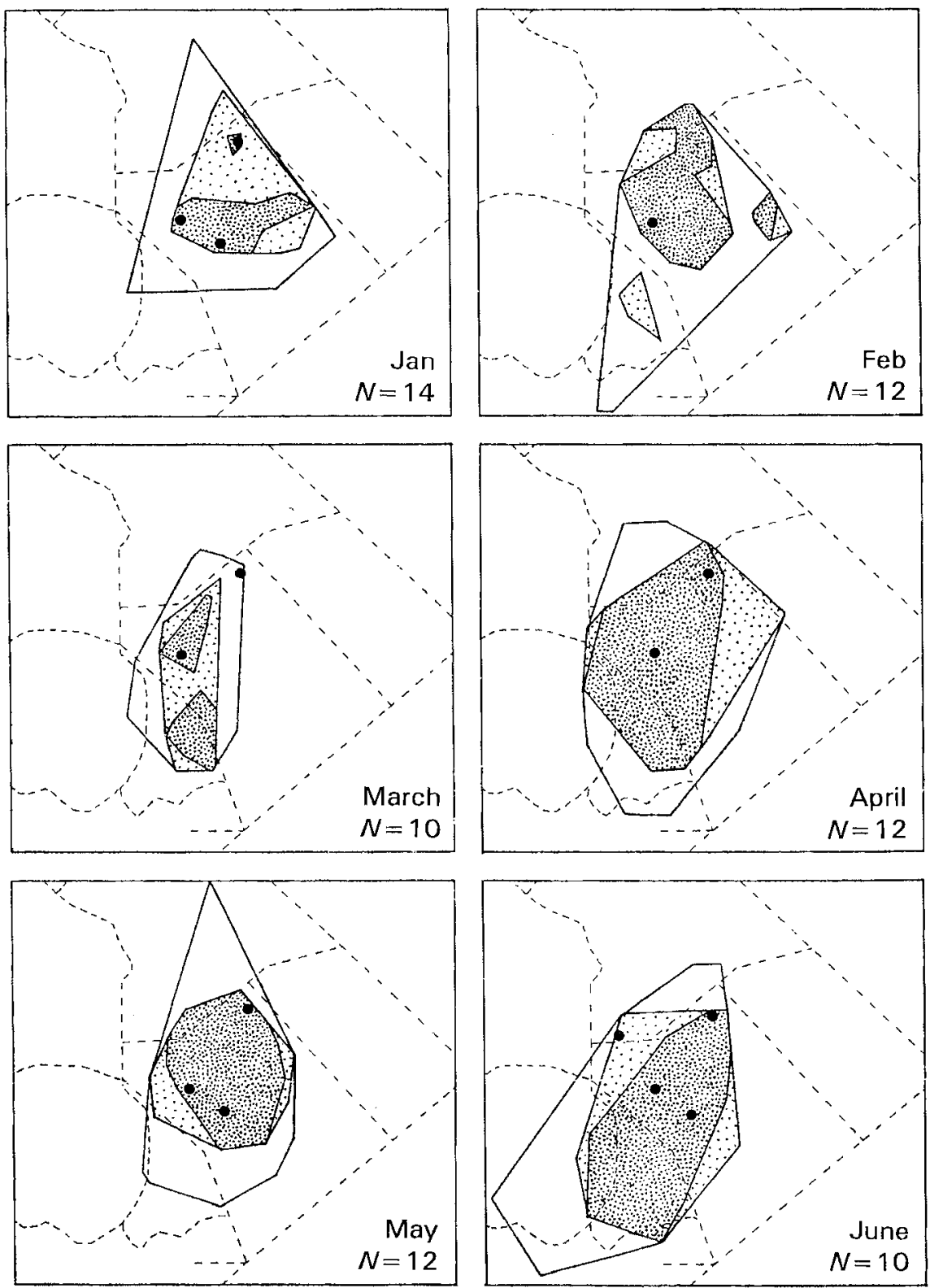

$1 \mathrm{~km}$

Fig. 1. Monthly home ranges ( $N=$ number of nights data) of a natural foraging male porcupine (M2), illustrating home range size fidelity, burrow occupancy, monthly changes in range size and the relative sizes of $100 \%(\square), 95 \%$ (溇) and $90 \%$ (圈) clusters.

home range size $(P>0 \cdot 10)$. Crop foragers had larger mean range sizes than natural foragers in both winter and summer, all differences being significant $(P<0.02$ or $P<0.01)$ except for $90 \%$ clusters in winter $(P<0 \cdot 10)$. 
Table 2. An analysis of seasonal variation in mean percentage overlap ( $\bar{x})$ of home range overlap of pairs members, of natural foraging neiglbours and of crop foraging neighbours (see text for definition of range use categories)

\begin{tabular}{|c|c|c|c|c|c|c|c|c|c|c|c|c|}
\hline \multirow{3}{*}{$\begin{array}{l}\text { Social } \\
\text { category }\end{array}$} & \multirow{3}{*}{$\begin{array}{r}\text { Range } \\
\text { use } \\
\text { category }\end{array}$} & & & & \multicolumn{6}{|c|}{ Percentage overlap } & \multirow{3}{*}{$\begin{array}{l}\text { Mann- } \\
\text { Whitney } \\
U \text {-value }\end{array}$} & \multirow[b]{3}{*}{$P$-value } \\
\hline & & \multicolumn{3}{|c|}{ Winter } & \multicolumn{3}{|c|}{ Summer } & \multicolumn{3}{|c|}{ Total* } & & \\
\hline & & $\vec{x}$ & Range & $N$ & $\vec{x}$ & Range & $N$ & $\bar{x}$ & Range & $N$ & & \\
\hline \multirow[t]{3}{*}{ Pairs } & $100^{\circ}$ & 75 & $47-96$ & 10 & 78 & $22 \cdots 100$ & 16 & 77 & $22-100$ & 26 & $58 \cdot 0$ & $>0.01$ \\
\hline & $95 \%$ & 75 & $49-100$ & 10 & 73 & $33-100$ & 16 & 74 & $33-100$ & 26 & $74 \cdot 5$ & $>0.01$ \\
\hline & $90 \%$ & 73 & $38-100$ & 10 & 69 & 38100 & 16 & 71 & 38100 & 26 & $70 \cdot 5$ & $>0.01$ \\
\hline Natural & $100 \%$ & 18 & $0-76$ & 50 & 8 & $0-73$ & 72 & $\cdots$ & 一 & - & 1076 & $<0.01$ \\
\hline foraging & $95 \%$ & 8 & $0-48$ & 50 & 0 & 0.2 & 72 & & - & & 1021 & $<0.01$ \\
\hline neighbours & $90 \%$ & 3 & $0-38$ & 50 & 0 & 0 & 72 & - & - & - & 1350 & $<0.01$ \\
\hline Crop & $100 \%$ & 14 & $22-52$ & 10 & 37 & $18-45$ & 8 & 39 & $18-52$ & 18 & 35 & $>0.01$ \\
\hline foraging & $95 \%$ & 16 & 6-28 & 10 & 24 & $10-44$ & 8 & 20 & $6-44$ & 18 & 23 & $>0.01$ \\
\hline neighbours & $90 \%$ & 4 & $1-11$ & 10 & 7 & $0-23$ & 8 & 6 & $0-23$ & 18 & 37 & $>0.01$ \\
\hline
\end{tabular}

*Values given when seasonal differences were not significant.

\section{Home range overlap}

Pair members shared home range areas with an average overlap of about $75 \%$, there being no significant seasonal differences in range sharing (Table 2). Natural foraging neighbours had significantly greater overlap with their neighbours in winter than in summer whereas crop foragers showed no significant seasonal difference in range overlap (Table 2). Crop foraging neighbours overlapped each other's ranges significantly more than natural foraging neighbours in both winter and summer $(P<0.05$, Mann-Whitney $U$-test $)$.

Home range overlap between pair members and neighbours in summer (November) and winter (May) is illustrated in Fig. 2. In November 1989 (Fig. 2a) fairly well-defined range boundaries can be seen between Pair 1 (M1 \& F1) and Pair 2 (M2 \& F2), and between Pair 2 and Pair 3 (M3 \& F3). The more extensive overlaps of a probable bachelor male's range (M5) are clearly illustrated, all other ranges being largely exclusive. Figure 2b (May 1990) illustrates the larger winter ranges with more extensive overlap as well as the considerably larger ranges of crop foragers, Pair 4 (M4 \& F4), and M6.

M5, a natural forager, exhibited significantly greater, aseasonal, range overlap with his neighbours than did other natural foragers. Total home range overlap was $28 \%$ and the $90 \%$ cluster's overlap was relatively high at $9 \%$.

\section{Temporal space-use patterns}

From maps plotted while radiotracking, the following observations were made: Pair 1 appeared to move independently of each other although they were often found in the same general area. Pair 2 often followed similar routes for several hours, usually at the beginning of the night, after which they moved in a similar manner to Pair 1, as did Pair 3. Pair 4, however, usually followed very similar

(C) East African Wild Life Society, Afr. J. Ecol., 34, 1-14 
8 N. U. Corbet and R. J. Van Aarde

(a)
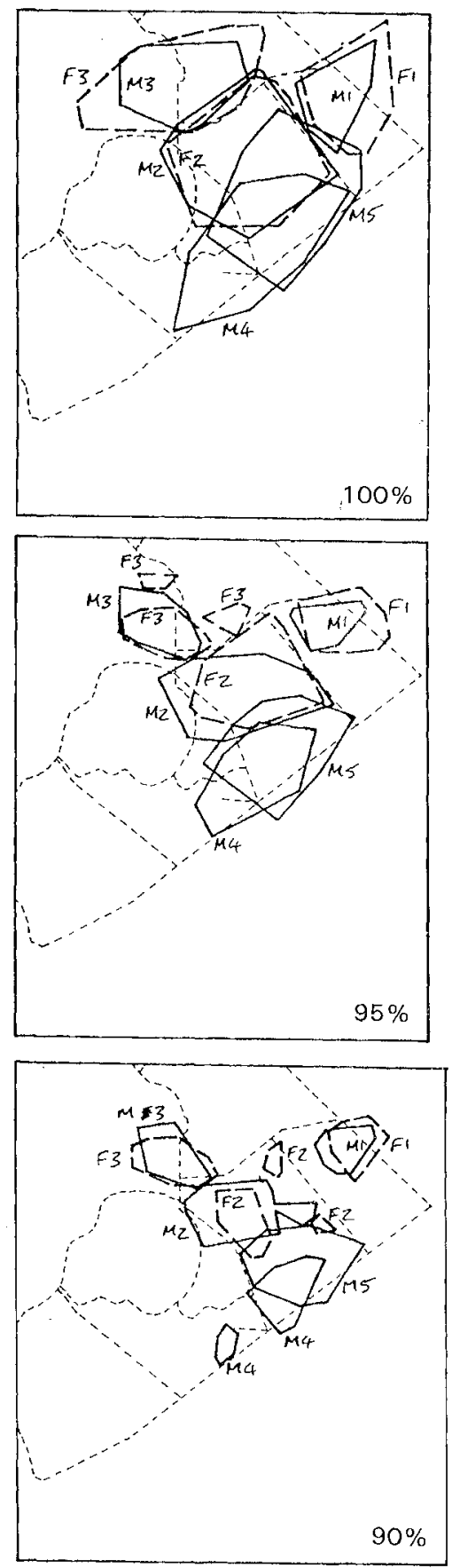

(b)
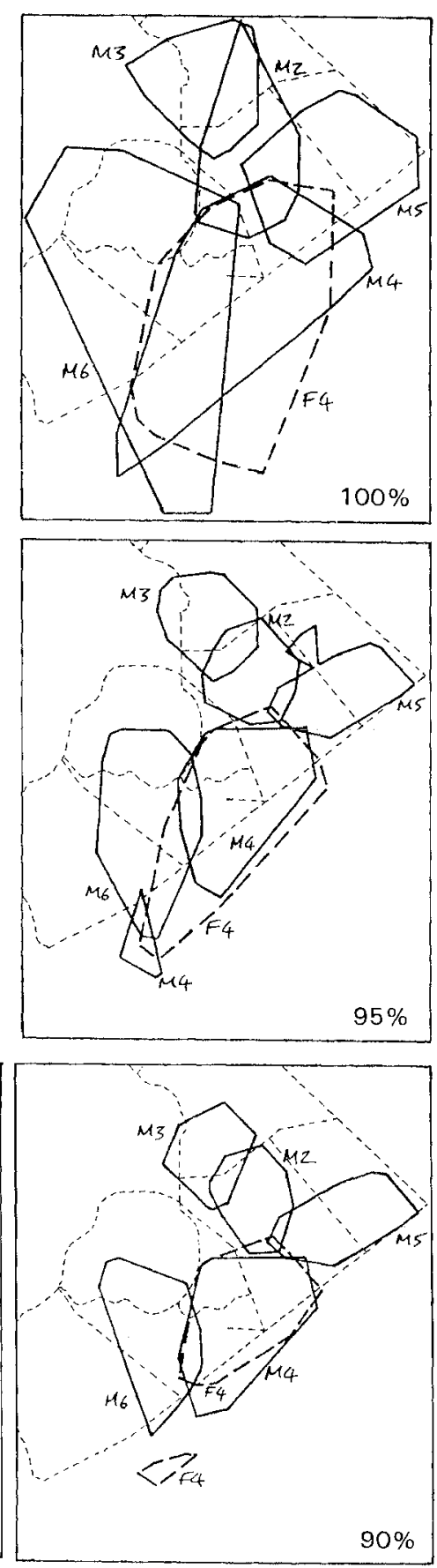

Fig. 2. (a) Home range areas of all porcupines radiotracked in November 1989 illustrating range overlap. (b) Home range areas of all porcupines radiotracked in May 1990 illustrating range overlap.

(1) East African Wild Life Society, Afr. J. Ecol., 34, 114 
(a)

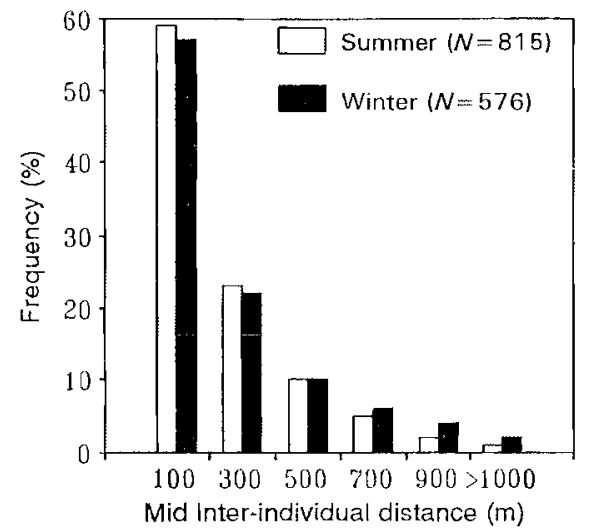

(b)

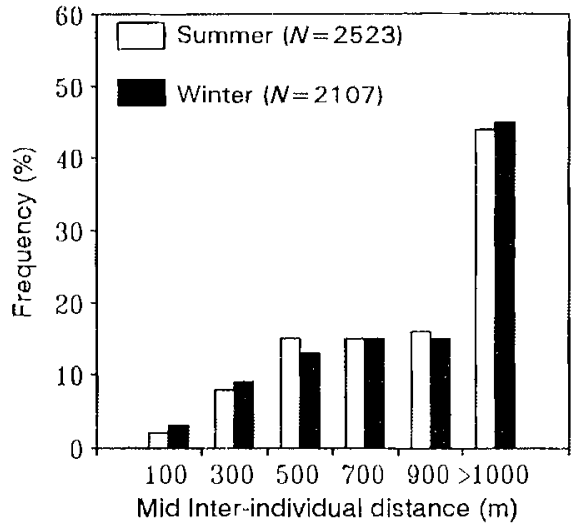

Fig. 3. Temporal space use patterns measured as frequency of observations in each inter-individual distance (IID) category: (a) pair members, (b) neighbours, in summer and winter.

routes for the entire night, presumably moving together. It appeared that neighbouring porcupines rarely encountered one another.

These observations were confirmed by temporal space-use analysis which indicated that pair members spent over $50 \%$ of their time within $200 \mathrm{~m}$ of each other and less than $25 \%$ of their time further than $400 \mathrm{~m}$ apart (Fig. 3). Neighbours, on the other hand, spent less than $5 \%$ of their time within $200 \mathrm{~m}$ of each other and over $85 \%$ of their time further than $400 \mathrm{~m}$ apart (Fig. 3). Male and female neighbours, male neighbours and female neighbours all showed similar patterns of temporal space-use and therefore data were combined. Similar patterns were obtained in both seasons, although neighbours exhibited slightly lower frequencies of observations in the lower IID categories in summer, as might be expected as a result of less range overlap in that season (Table 2). Note than even if an individual was constantly interacting with its neighbours, a frequency score of more than $25 \%$ in the $<200 \mathrm{~m}$ IID category would not be expected. This is because each individual's range is bordered by about four other ranges; thus, if an individual is interacting with the neighbour or pair of neighbours, it will almost certainly fall into the higher IID categories with respect to its other three sets of neighbours, such that a maximum of $25 \%$ of observations may fall within the $<200 \mathrm{~m}$ IID category. Despite these limitations, the observed frequency of close interactions still falls well below this potential $25 \%$ level.

\section{Interactions}

Only five interactions between individuals were recorded during 153 nights of radiotracking. One of these involved M1 and M5 roaming together for approximately seven hours one night, the significance of which, if any, is unknown. On two occasions $\mathrm{Fl}$ and M5 were recorded to share a burrow during the day. On another occasion F1 and M2 appeared to encounter one another while foraging and then moved together towards Fl's burrow where they spent approximately two hours before separating at dawn. $\Lambda$ ll three of the interactions involving $F 1$

(1) East African Wild Life Society, Afr. J. Ecol., 34, 1. 14 
occurred during a two-week period in September 1989. The fifth interaction occurred following the death of F4 who was shot on a neighbouring farm in June 1990. The night after F4 was shot, M4 left the burrow that they had occupied exclusively for the previous three months. At dawn M4 returned to the vicinity of the burrow but then moved to another nearby burrow. That same morning M5 moved into Pair 4's burrow where he stayed for the remainder of the study. Whether or not this takeover was the result of a direct encounter could not be determined from the radiotracking data.

\section{Discussion}

\section{Social organization}

The observations presented here suggest that adult Cape porcupines in the study area live in pairs. Juveniles were never caught although they were seen in the study area and are assumed to live with their parents as a family group (Van Aarde, 1987b). There was no evidence of more than two adults cohabiting, thus extended family groups are thought not to occur in this area. All pairs were temporarily stable during the study period, with pair members sharing burrows and home range areas. Thus, the monogamous pair bond described by Morris \& Van Aarde (1985) for captive porcupines and for free-ranging porcupines (Van Aarde, 1987b) also appears to exist at Nylsvley. Monogamous pair bonds also have been noted for captive crested porcupines (H. cristata) and Indian crested porcupines ( $H$. indica) and may therefore be a feature of this genus (Pigozzi, 1987; Sever \& Mendelssohn, 1988).

Few mammalian species $(\approx 3 \%)$ are monogamous (Kleiman, 1977) and monogamy is expected to evolve only in situations where males are unable to secure relatively exclusive access to more than one female, perhaps due to the pattern of female dispersion coupled with either synchronized oestrus or polyoestrus (MacDonald, 1983; Mock \& Fujioka, 1990). However, once monogamous the only way a male can increase his reproductive success, apart from extra-pair matings, is to invest in parental care. Thus, in common with many other monogamous males, male porcupines do care for their offspring by accompanying them on foraging trips, grooming and providing thermoregulatory benefits through huddling (Van Aarde, 1987a).

Family groups appear to be typical of the social organization of the Cape porcupine (Shortridge, 1934; Smithers, 1971; Van Aarde, 1987a,b). Shortridge (1934) and Van Aarde (1987b) both observed up to 14 individuals sharing a burrow. However, since the age structure, sex ratio and temporal stability of these groups are unknown, their significance is uncertain. However, Van Aarde (1987a) identified two extended family groups in the semi-arid Karoo region of South Africa, each consisting of an adult pair, two subadults and two juveniles. Thus, the Cape porcupine appears to have a variable social organization. This has also been recorded in Indian crested porcupines which live in family groups on the coastal plain of Israel (Sever \& Mendelssohn, 1991) and in extended family groups in the Negev desert (Saltz \& Alkon, 1989).

A family group may develop as a result of immature offspring remaining with the parental pair. The dispersal of mature offspring may, however, be affected by reproductive opportunities available to them within their natal group. In 
the Cape porcupine only the dominant adult pair reproduce and although subordinate females display oestrous cycles and incestuous copulations occur, it is only the dominant female that conceives (Van Aarde, 1985a; Van Aarde \& Van Wyk, 1991). Reproductive suppression should result in mature offspring dispersing from their natal group as soon as possible, thus enabling them to maximise their reproductive opportunities. Extended porcupine family groups thus should only develop where opportunities for dispersal are restricted. Barriers to dispersal may include a lack of vacant territories as a result of high population densities (Van Aarde, 1987a,b) or limited resources, e.g. food or burrows.

During the present study pairs within the Reserve spent over $50 \%$ of their night-time activities within 200 metres from each other. The small number of interactions recorded suggest that extra-pair matings may occur but that these are uncommon and opportunistic as would be expected in a monogamous species. Sever \& Mendelssohn (1991) recorded several non-territorial, bachelor males and that pair members always foraged in very close proximity to one another. Such close contact may serve as a mate-guarding function since there is no evidence that porcupines cooperate in anti-predator defence, territorial fights or foraging.

The main benefits of group living for porcupines are probably thermoregulatory huddling (Haim, Van Aarde \& Skinner, 1992), the cooperative rearing of offspring, the sharing of burrows and possibly the cooperative maintenance of territories. However, the incident in which a burrow was taken over immediately following the death of one pair member, suggests that the pair-bond may provide an extra incentive to maintain a territory, even if both pair members are not directly engaged in territorial maintenance.

\section{Space use}

Individual porcupines utilize the same general area throughout the year. However, most activity was concentrated in a relatively small portion of the potentially larger area. However, the actual area of intensive use varied in location from month to month. It is probably advantageous to minimize the area used in order to minimize the costs of foraging and territorial defence. The home ranges of natural foraging pairs were largely exclusive, with only winter total home ranges showing any substantial overlap (Table 2). As most overlap involved only total home ranges, i.e. only $5 \%$ of locations, overlapping areas do not appear to be extensively utilized. Additionally, temporal space-use analysis (Fig. 3) shows that neighbouring individuals, regardless of sex or season, rarely come into contact with one another. Such a pattern of space use, i.e. a small, exclusive, intensively used area within a larger, non-exclusive sparsely utilized area, suggests territoriality. However, as home range areas do not always occupy exactly the same position from month to month, territorial boundaries do not appear to be permanent or rigidly defined. The large, non-exclusive areas may serve as a buffer zone between neighbouring territories and may allow individuals to shift their centres of activity in response to short-term changes in local resource availability without incurring territorial disputes. We did not record any form of regular boundary patrolling as has been described in male African brush-tailed porcupines (Atherurus aficanus) by Emmons (1983). Tcrritories are 
probably maintained indirectly by scent marking rather than directly through aggressive encounters. The overlapping 'buffer zones' surrounding the territories probably enhance such indirect communication between neighbours (Brown \& Orians, 1970). Familiarity between neighbours resulting from scent marking allows mutual avoidance, decreased aggression and consequently reduces the cost of territorial maintenance (see Randall, 1989).

The home ranges of crop foragers overlapped to a significantly greater extent than natural foragers with no significant seasonal variation (Table 2). Overlap between total home ranges was considerable (39\%) and even $90 \%$ clusters had a mean overlap of $6 \%$. This and aseasonality of range overlap in crop foragers is probably attributable to the presence of an artificial resource concentration in the form of crops of maize and watermelons. It is probable that this resource is so abundant that it is unnecessary, and therefore uneconomic, to defend it. Thus territorial behaviour breaks down in the area around the resource, resulting in increased range overlap. Artificial food supplies have been known to cause aggregations of normally territorial animals of several species, e.g. golden jackals (Canis aureus) attracted to rubbish tips in Israel (MacDonald, 1983).

A natural forager, M5, exhibited significantly greater, aseasonal, range overlap with his neighbours than did other natural foragers. This is thought to be due to him being a single male. Possibly there was insufficient space and he was unable to maintain an exclusive territory suggesting that a pair may be able to defend a territory more effectively than a single animal. Alternatively, he may have actively trespassed on neighbouring territories in search of extra-pair copulations, as was perhaps recorded in the interactions described.

Variations in resource dispersion probably account for much of the intraspecific variability in territoriality and social organization observed in many species (Brown \& Orians, 1970; MacDonald, 1983; Kruuk \& MacDonald, 1985; Carr \& MacDonald, 1986). The larger winter ranges of natural foragers (Table 1, Fig. 2) probably result from the reduced availability of food in the dry winter season which forces animals to forage over a wider area than in the more productive wet summer season. Crop foragers which were less dependent upon natural vegetation exhibited no significant seasonal variation in range size (Table 1). Saltz \& Alkon (1989) also recorded that crop foraging Indian crested porcupines showed little seasonal variation in range size compared to natural foragers. Porcupines living in a seasonally variable environment do not therefore appear to maintain a constant territory size, it being economically not viable to defend a large area in summer when resources are not limited. Thus, porcupines do not appear to follow Von Chantz's (1984) "Constant Territory Size Hypothesis" which suggested that changing territorial boundaries was more costly than maintaining a permanent territory of sufficient size to support the animals in times of minimum resource abundance. The porcupines in the study area therefore behave as seasonal contractors (Kruuk \& MacDonald, 1985). Further evidence for this was the lack of range expansion by M2 and M5 following the death of their neighbours, Pair 1, at the end of January 1990. M5 did eventually occupy part of Pair 1's range but not until winter range expansion in May 1990. Cheeseman et al. (1988) observed similar contractionism in European badgers, Meles meles, following the removal of neighbouring clans.

(C) East African Wild Life Society, Afr. J. Ecol, 34, 1-14 
In the case of a social species, territory size may increase proportionately to group size if resources are evenly dispersed. Alternatively, the Resource Defence Hypothesis (MacDonald, 1983; Carr \& MacDonald, 1986) suggests that territory size may be independent of group size if resources are patchily dispersed such that the area necessary to support one individual can support several additional animals. Porcupines may allow their mature offspring to remain in their natal group if the parental territory is sufficiently large as a result of patchy resource dispersion and opportunities for dispersion are limited. This may explain the presence of the extended family groups recorded in the Karoo and the Negev desert (Van Aarde, 1987a; Saltz \& Alkon, 1989). In areas such as Nylsvley where food for porcupines appears to be widely distributed (De Villiers, Van Aarde \& Dott, 1994), territories are relatively compact and may contain insufficient resources to support additional animals. Thus, mature offspring may be forced to leave their natal territory, perhaps even if there is a lack of vacant alternative territories. Although mature offspring may help to look after their younger siblings, there do not appear to be sufficient benefits to group living for porcupines to form extended family groups in a situation where territorial resources are limited, particularly in view of the limited reproductive opportunities for the mature offspring.

\section{Acknowledgments}

We would like to thank Dr Hector Dott for assistance with data analyses programmes, Marienne de Villiers for helping with the collection of field data and the Mammal Research Institute for providing logistical support. The project was funded by the Foundation for Research Development (FRD) and the University of Pretoria (UP). Niall Corbet was supported by bursaries from FRD, UP, the Department of National Education and the Bob Blundell Memorial Scholarship. The Transvaal Provincial Administration (TPA) granted permission to work at Nylsvley Nature Reserve.

\section{References}

Brown, J.L. \& Orians, G.H. (1970) Spacing patterns in mobile animals. Ann. Rev. Ecol. Syst. 1, $239-262$. Carr, G.M. \& MacDonald, D.W. (1986) The sociality of solitary foragers: a model based on resource dispersion. Anim. Behav. 34, 1540-1549.

Cheeseman, C.L., Cresswell, W.J., Harris, S. \& Mallinson, P.J. (1988) Comparison of dispersal and other movements in two badger (Meles meles) populations. Mamm. Rev. 18, 51-59.

Coetzee, B.F., Van der Meulen, F., Zwanziger, S., Gonsalves, P. \& Weisser, P.J. (1976) A phytosociological classification of the Nylsvley Nature Reserve. Bothalia 12, 137-160.

De Villiers, M.S. \& VAN AARDE, R.J. (1994) Aspects of habitat disturbance by Cape porcupines in a savanna ecosystem. S. Afr. J. Zool. 29, 217--220.

DE Villiers, M.S., VAN AaRde, R.J. \& DotT, H.M. (1994) Habitat utilization by the Cape porcupine Hystrix africaecustralis in a savanna ecosytem. J. Zool., Lond. 232, 539-549.

Emmons, L.H. (1983). A field study of the African brush-tailed porcupine, Atherums africanus, by radiotelemetry. Mammalia 47, 183-194.

Hajm, A., VAN Aarde, R.J. \& Skinner, J.D. (1992) Burrowing and huddling in newborn porcupine: the effect on thermoregulation. Physiology \& Bchavior 52, 247-250.

KeNward, R. (1987) Wildife Radio Tagging: Equipment, Field Techniques and Data Analysis. Academic Press, London.

Kliman, D.G. (1977) Monogamy in manmals. Q. Rev. Biol. 52, 3969.

(C) East African Wild Life Society, Afr. J. Ecol., 34, 1-14 
KRUUK, H. \& MaCDONALJ), D.W. (1985) Group territories of carnivores: empires and enclaves. In: Behavioural Ecology (Ed. R.M. Sibley and R.H. Smith). Blackwell Scientific Publications, Oxford.

KrUUK, H. \& Parish, T. (1982) Factors affecting population density, group size and territory size of the European badger, Meles meles. J. Zool., Lond. 196, $31 \cdots 39$.

MacDonald, D.W. (1983) The ecology of carnivore social behaviour. Nature 301, 379-384.

Mock, D.W. \& FuJiokn, M. (1990) Monogamy and long-term pair-bonding in vertebrates. Trends Ecol. Evol. 5, 39-43.

Morris, D.J. \& VAN Aaride, R.J. (1985) Sexual behaviour of the female porcupine Hystrix africaeaustralis. Horm. Behav. 19, 400-412.

PIGozzI, G. (1987) Female-biased sexual size dimorphism in the crested porcupine (Hystrix cristata L.). Boll. Zool. 54, 255-259.

RANDALL, J.A. (1989) Territorial defense interactions with neighbours and strangers in banner-tailed kangeroo rats. J. Mammal. 70, $306-315$.

SALTZ, D. \& AlKon, P.U. (1989) On the spatial behaviour of Indian crested porcupines (Hystrix indica). J. Zool., Lond. 2171, 255 -266.

Scholes, R.J. \& Walkfr, B.H. (1993) An African Savama: Synthesis of the Ny/spley Study. Cambridge University Press, Cambridge.

Sever, Z. \& MendelssoHn, H. (1988) Copulation as a possible mechanism to maintain monogamy in porcupines, Hystrix indica. Anim. Behav. 36, 1541-1542.

Saver, Z. \& MENDELSsoHn, H. (1991) Spatial movement patterns of porcupines (Hystrix indica). Mammalia 55, 187-205.

Shortridge, G.C. (1934) The Mummals of South West Africa, Vol. 1. Heinemann, London.

SkInNer, J.D. \& SMtThers, R.H.N. (1990) The Mammals of the Southern African Subregion. University of Pretoria.

Smithers, R.H.N. (1971) The Mammals of Botswana. Museum Memoir No.4, The Trustees of the National Museums of Rhodesia, Salisbury.

SPRINGER, J.T. (1979) Some sources of bias and sampling error in radio triangulation. J. Wildl. Manage. 43, 926-935.

VAN AARDE, R.J. (1985a) Reproduction in captive female Cape porcupines (Hystrix africaeaustralis). $J$. Reprod. Fert. 75, 577-582.

VAN AARDe, R.J. (1985b) Husbandry and immobilization of capital porcupines Hystrix africaeaustralis. $S$. Afr. J. Wild. Res. 15, 77 79.

VAN AARDE, R.J. (1987a) Demography of a Cape porcupine, Hystrix africueaustralis, population. J. Zool., Lond. 213, 205-212.

VAN AARDE, R.J. (1987b) Reproduction in the Cape porcupine Hystrix africaeaustralis: an ecological perspective. S. Afr. J. Sci. 83, 605-607.

VAN AARDE, R.J. \& VAN WYK, V. (1991) Reproductive inhibition in the Cape porcupine, Hystrix africaeaustralis. J. Reprod. Fert. 92, 13-19.

Von SChantz, T. (1984) Carnivore social behaviour--does it need patches? Nature 307, 389-390.

Yeaton, R.I. (1988) Porcupines, fires and the dynamics of the tree layer of the Burkea africana savanna. J. Ecol. 76, 1017-1029.

(Manuscript accepted 27 February 1995) 